\title{
Effect of Using Mind Maps on Understanding Islamic Education Curriculum
}

\author{
Abdul Hamid Abdullah Ibrahim ${ }^{1}$, Saleh Al-Azmey ${ }^{2}$ \\ ${ }^{1}$ Professor of Methodology and Teaching Arabic Language Faculty of Education, Tanta University \\ ${ }^{2}$ Ph.D. Researchers, Faculty of Education, Tanta University
}

\begin{abstract}
Relaying on Teaching Islamic Education Curriculum, The Researcher Realized That The Subject Is Taught By A Classical Styles Depending on Dictation By Teachers, Hence Students' Lack In Motivation Towards It. Thus, The Researcher Tried To Increase The Effectiveness of Teaching The Subject By Using Mind Maps. The Research Sample Included (50) Students in Prep Stage of Islamic Education Class. The Researcher Prepared An Approach Measure Towards Islamic Education Containing (40) Positive \ Negative Clauses Distributed To (3) Axes Controlled By Relative Importance And Experts' Opinions. Results Showed Statistically Significant Differences Between The Pre \ Post Applications of The Experiment Group In Approach Test At The Favor of The Post Application.
\end{abstract}

Keywords: Mind Maps, Prep Stage, Approach Measure, Islamic Education

\section{Introduction}

Education Is Considered One of The Most Important Phenomena Which Play an Important Role In Peoples' Progress Which Is Measured By Using Modern Styles and Strategies; The Thing Which Transforms The Classical Environment of Teaching Into A Competitive And Cooperative One Between Students and Teachers Who Shoulder The Responsibility of Improving The Educational Process(3). Mind Maps Are One of These New Strategies Which Serve an Exciting And Funny Environment For Students To Learn. Besides, They Help Students To Create And Focus While Learning. Also, They Liberate Education From Classical Styles Controlled By Teachers and Increase Students' Activity, Participation And Self - Confidence. They Help Students To Self Learn. Tony Bozran Invited Mind Map (2).

Studies Referred That Most Learners Have Visual Memory, So Mind Maps Help Those Who Have Weak Memory To Remember Details of Visual Pictures And Help In Following Ideas In A Creative Way(8). Cognitive Maps Are Another Modern Way for Learning In Which Learners Are Active And Ready To Understand Lessons Fast, Hence Better Performance And School Achievement For Students. That New Style Helps Greatly To Develop Cognitive Concepts Standing on Hierarchical Meaningful
Relationship Which Keep The Learners Thinking Continuously (4). The Importance of Using Cognitive Maps In The Educational Process And How Effective They Were on Modifying Approaches And Increasing Academic Achievement (6). Not Only Students But Also Teachers Who Use Cognitive Maps In Teaching Students Skills of Analysis And Finding Relationships Logically (9).

Modern Strategies Workshop at Ministry of Education In Riyadh (2005) Referred To The Difference Between Cognitive Maps And Mind Ones. The Former Is A Plan Put By Teachers To Present Their Lessons To Help Students To Understand In A Logic Way, Whereas The Latter Is Creative Map Representing The Student's Vision Towards The Relationships Inside The Subject (10).

Experts See Using Internet As A Mean of Information Technology Becomes A Necessity All Over The World; The Thing Which Maximizes Quality And Interaction Between Teachers And Students. Nowadays, Internet Is So Important Because It Serves Opportunities For Students To Gain A Lot of Information In No Time And In Any Place (11).

In His Study, Moras (2001) Using Internet In Studying Subjects By Students Who Work Positively And Are Motivated To Learn (12).

\section{Methodology}


The Researcher Applied The Experiments Method on The Research Sample By Using Before And After Application. (50) Students Were Chosen Randomly From Prep Schools In Kuwait In The First Term of The Year (2018/2019). Referring To Previous Studies, The Researcher Didn't Find An Approach - Oriented Test, So The Researcher Designed An Approach Test Towards Islamic Education After Referring To Previous Studies, Journals And Arab And Foreign References Specializing In Designing Tests. The Approach Test Was Designed By Defining Goal of The Measure, Analyzing The Content, Out Lining Axes of The Test And Evaluating The Test By Experts. The Approach Measure towards Islamic Education Included (40) Positive and Negative Clauses Distributed To (3) Axes In Accordance With Relative Importance and Experts' Opinions. Axes of The Test Were Approach Towards Islamic Education In Educational Process, Approach Towards Knowledge In Islamic Education, and Approach Towards Islamic Education In General. (SPSS) Program Was Used To Analyze Results.

\section{Results}

Results Show Differences With Statistical Differences Between The Pre $\backslash$ Post Application of The Experiments Group At The Favor of The Post One; Calculated Value of "T" Was1.994 Which Was Higher Than The Table Value of "T" (0.05).

Table (1) pre and post application and differences between means of test axes

\begin{tabular}{|l|l|l|l|l|}
\hline \multicolumn{1}{|c|}{ Axis } & \multicolumn{2}{|c|}{ measurement } & $\begin{array}{c}\text { Difference } \\
\text { between } \\
\text { means }\end{array}$ & $\begin{array}{c}\text { "T" } \\
\text { value }\end{array}$ \\
\cline { 2 - 4 } & Pre & post & 17.73 \\
\hline $\begin{array}{l}\text { The Trend Towards } \\
\text { Islamic Education In } \\
\text { The Educational } \\
\text { Process }\end{array}$ & 12.5 & 18.80 & 6.30 & 24.20 \\
\hline $\begin{array}{l}\text { The Trend Towards } \\
\text { Knowledge And } \\
\text { Knowledge In Islamic } \\
\text { Education }\end{array}$ & 10.8 & 16.20 & 5.40 & 16.31 \\
\hline $\begin{array}{l}\text { The Trend Towards } \\
\text { Islamic Education As } \\
\text { Important }\end{array}$ & 12.54 & 18.90 & 6.36 & \\
\hline
\end{tabular}

*Table value $(\mathrm{t})$ at $0.05=1.9$

Table (1) Shows That There are Statistically Significant Differences Between The Pre \ Post Application of The Experiments Group In The Trend Test In Question In Favor of Post Measurement, As The Calculated (T) Value Is Greater Than The (T) Table Value At The Level of The Indication of (0.05)

\section{Discussion}

By Analyzing The Previous Results, The Following was Concluded: -:

1) Using Technology In Educational Process Is Positive In Teaching.
2) Using Mind Maps In Teaching Formed Positive Approaches Towards Islamic Education.

3) Using Mind Maps Maximized Achievement and Improving Educational Process.

4) Programming Subjects Help Both Learner and Teacher To Achieve Goals.

\section{Recommendations}

1- It Is Necessary To Use Mind Maps in Teaching.

2- Using Online Websites to Exchange Views and Increase Effectiveness of Teaching Subjects.

3- It Is Important To Hold Courses And Sessions To Keep In Touch With Anything New In Education.

4- It Is Essential To Use All Kinds of Maps For Its Effective Role In Educational Process.

\section{References}

[1] Ahmed Kandil: Teaching with New Technology, 1st edition, World of Books, Cairo, 2006 AD.

[2] Ahmad Al-Lakan\& Ali Al-Jama(1996): A Dictionary of Educational Terms, Knowledge in Curricula and Teaching Methods, 1st Edition, World of Books,

[3] Hassan Zaitoun(1999) .Teaching Design, World of Books, Volume II,

[4] Zaytoun Mahmoud (1994) Methods of Teaching Science, 1st floor, Amman, Dar Al-Shorouk,

[5] Safwat Ali: The effect of an educational program using cognitive maps on learning to pay the shot for students of the Education Division, Faculty of Physical Education, 2004 AD.

[6] Abdullah Al-Mousa, Fahd Al-Fahd(2000) Studying the role of communication services in the Internet in developing learning systems in higher education institutions, College of Education Research Center, King Saud University,

[7] Effat Mostafa El-Tanawi(2002). Teaching and Learning Methods and their Applications in Educational Research, 1st edition, The Anglo Egyptian Library, Cairo,

[8] Fadia Muhammad (2002).The effect of learning using cognitive maps on the cognitive and skill achievement of some skills in handball, Ph.D. thesis, College of Physical Education for Girls, Helwan University.

[9] Fakhruddin Al-Ula(2006 ) General Teaching Methods in the Information Age, University Book House,

[10] Kawthar Kojak(1997).Modern Trends in Curricula and Teaching Methods, The World of Books, Cairo.

[11] Muhammad al-Hadi(2005) e-learning via the Internet, the Egyptian Lebanese House, 1st edition,

[12] Muammar Al-Azza(2001) The effect of using chemistry with cognitive maps on the development of test anxiety among ninth grade students, MA, AlAqsa University, Gaza.. 